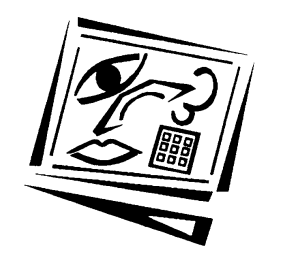

\title{
Second Life machinima enhancing the learning of law: Lessons from successful endeavours
}

\author{
Des Butler \\ Queensland University of Technology
}

\begin{abstract}
A traditional approach centred on weekly lectures, perhaps supported by tutorials, still predominates in modern legal education in Australia. This approach tends to focus on the transmission of knowledge about legal rules and doctrine to students, who adopt a largely passive role. Criticisms of the traditional approach have led to law schools expanding their curricula to include the teaching of skills, including the skill of negotiation and an appreciation of legal ethics and professional responsibility. However, in a climate of limited government funding for law schools in Australia innovation in legal education remains a challenge. This article considers the successful use of Second Life machinima in two interactive multimedia programs, Air Gondwana and Entry into Valhalla, and their part in the creation of engaging, effective learning environments. These programs not only engage students in active learning, but also facilitate flexibility in their studies and other benefits. The programs yield important lessons concerning the use of machinima innovations in curricula for academics involved in legal education as well as those in other disciplines, especially those that rely on traditional passive lectures in their teaching and learning approaches.
\end{abstract}

\section{The deficiencies of traditional legal education}

Until relatively recently, the methods used to teach law in Australia had changed little from the time of the establishment of the first law schools in the 1850s. In the traditional model that has dominated legal education in this country,

most teachers uncritically replicate the learning experiences that they had when students, which usually means that the dominant mode of instruction is reading lecture notes to large classes in which students are largely passive. (Keyes \&

Johnstone, 2004, p. 539)

This approach has a long pedigree. Dicey (1883, cited in Sugarman, 1986, p. 30) suggested that nothing "can be taught to students of greater value, either intellectually or for the purposes of legal practice, than the habit of looking upon the law as a series of rules." The primary focus of traditional legal education is the transmission of content knowledge, in particular the teaching of legal rules, such as rules drawn from case law (Pearce, Campbell \& Harding, 1987).

The traditional model is described by Web (1996, p. 23) as follows:

Traditionally law is taught through a series of lectures, with little or no student involvement, and a tutorial programme. Sometimes tutorials are referred to as seminars but the terminology used is often insignificant: both terms refer to probably the only form of student participation that takes place throughout these students' 
academic legal education. The tutorial consists of analysing the answers, prepared in advanced [sic], to artificial Janet and John Doe problems or esoteric essay questions.

This model has been the subject of stringent criticism, both for its emphasis on the transmission of knowledge about legal rules and doctrine and the manner in which the law is taught (Pearce et al., 1987). Nevertheless, in 1992, the Consultative Committee of State and Territorial Admitting Authorities, headed by Justice Priestley of New South Wales, compiled a list of compulsory subject areas for academic legal study, known as 'the Priestley 11', which individuals must complete in order to be admitted to legal practice. While this list - which comprises 'substantive law' areas such as contract law and criminal law as well as the formal rules of professional responsibility - does not directly affect law curricula, Australian law schools still typically structure their degrees to accommodate the list so that their graduates may qualify for entry into legal practice. This is most easily discharged by means of the traditional model.

Seminal reviews in the 1990s, both in Australia and overseas, also criticised the focus on teaching legal content without paying sufficient attention to the teaching of legal skills (American Bar Association [ABA], 1992; Advisory Committee on Legal Education and Conduct [ACLEC], 1996; Australian Law Reform Commission [ALRC], 1999). Such reviews advocated a greater focus on "what lawyers need to be able to do, [rather than being] anchored around outmoded notions of what lawyers need to know" (ALRC, 1999, para. 2.21). In a major review of legal education conducted in the United States in 1992, 10 fundamental lawyering skills were identified, including negotiation and the ability to recognise and resolve ethical dilemmas (ABA, 1992, pp. 139-40). A 1996 United Kingdom report on legal education and training similarly emphasised the need for legal education to focus on development of skills other than advocacy and analysis of appellant court judgments to include training in areas such as negotiation and ethics associated with decision making (ACLEC, 1996, p. 15). In endorsing these observations, the Australian Law Reform Commission noted the advantages of combining the teaching of such skills within substantive law subjects, giving as an example the law of contracts, which provided opportunities for skills development in negotiation and the ethical considerations involved in negotiations (ALRC, 1999, para. 2.78).

Many law schools have attempted to respond to this call, for example, by also including in their curricula programs aimed at developing the skills of their students and through greater use of technology (Johnstone \& Vignaendra, 2003). Further impetus for innovation and experimentation has also been provided by the desire to meet the changing expectations of a new generation of students, who generally want the flexibility to access their study materials at their own convenience and in their own way (McGarr, 2009). Nevertheless, the track record of Australian law schools in teaching legal ethics, for example, has been described as less than impressive (Robertson, 2004). A study for the Australian Universities Teaching Council in 2003 found that the commitment to ethics learning in Australian law schools was far from uniform (Johnstone \& Vignaendra, 2003). Another study found that some Australian law schools that had introduced dedicated ethics and professional responsibility subjects into their curricula appeared to be relatively uncommitted to their development, success and implementation (Le Brun, 2001). While ethics training should ideally be done in a clinical setting, dealing with the problems of real people (Boon, 2002; Stuckey, 2007), by its nature, clinical education can be offered only to a small number of students (Castles, 2001). According to the Law Council of Australia 
(LCA, 2008), clinical programs are also so expensive that only a handful of law schools have been able to fund them. Teaching legal ethics using the traditional model that focusses on the content of professional responsibility rules is seen by many law schools as a more cost-effective option. However, the New South Wales Law Reform Commission (1993) criticised this approach as being deficient:

\begin{abstract}
The Commission wishes to make clear its view that it is inadequate to teach legal ethics and professional responsibility as if these are matters are [sic] etiquette which must simply be transmitted, committed to memory and recalled on the appropriate occasions (such as at the examination). Rather, these are matters which are bound up in the fundamental nature and essence of lawyering and legal professional practice, which necessitates a process or problem-solving approach to the subject. Ideally this involves a clinical approach, and certainly the opportunity for reflection and discussion, but in any event we regard the 'large lecture' as an unsuitable pedagogical technique (and the large lecture hall an unsuitable venue) for creating a professional sensibility and developing a thoughtful and lasting commitment to ethical conduct. (para. 5.24, emphasis in original)
\end{abstract}

Similarly, use of a traditional approach to the skill of negotiation may unintentionally reinforce misconceptions that the main or indeed sole focus should be on the bargaining phase of the negotiation rather than emphasising the importance of the thought processes that are required for proper preparation (Roper, 1983, p. 53). Effective negotiation training requires, at least, instruction on the principles of negotiation, a demonstration of negotiation in practice, a role-play conducted by the participants and a debriefing (Tyler \& Cukier, 2005). Further, without a close connection between a principle and relevant examples, novices typically are unable to take advantage of abstract principles and apply them to novel situations (Ross \& Kilbane, 1997). Negotiators need to have a strategic conceptualisation of the required preparation and bargaining situation in order to reach integrative solutions (Neale \& Northcraft, 1990).

Pressures of increased class sizes and a lack of resources are significant obstacles to law schools moving away from the traditional model (Johnstone \& Vignaendra, 2003). The relatively low government funding available to Australian law schools has been recognised as a significant impediment to innovation in the development of curricula and resources (LCA, 2008). This includes innovation through the development of multimedia, with the often-prohibitive cost of production, including video and computer software programming, a common barrier (deWinter, Griffin, McAllister, Moeller \& Ruggill, 2010; Dunning et al., 2004).

\title{
Second Life machinima contextualising the law
}

A virtual world may be regarded as

\begin{abstract}
A computer-based, simulated environment in which users are able to immerse themselves, and within which they are able to, through their avatars (computer-based representations of themselves or alternative selves), experience, manipulate, interact with and/or create virtual objects and places that are graphically depicted in three dimensions. The objects and places within a virtual world may be modelled according to those in the real world or may be fantasy based. (Lee, 2010, cited in Dalgarno, Lee, Carlson, Gregory \& Tynan, 2011)
\end{abstract}

The use of virtual worlds is not limited to synchronous or asynchronous 'in-world' interactions between students, or between students and academics. The creation of 
machinima - computer graphics imagery produced with the use of a virtual world such as Second Life rather than costly professional software or complex programming is equally an example of a user (in this case the machinima-maker, whether academic or student) immersing him/herself through their his/her avatar in a simulated environment modelled on the real world or fantasy. Machinima does not require students to enter the simulated environment themselves, but nevertheless is an important application of virtual worlds in tertiary education because it can be a costeffective means of creating effective learning environments (Middleton \& Mather, 2008). Technology has been recognised as an alternative to real-life settings such as clinical exercises, without needing to forego the critical authentic context (Herrington \& Oliver, 2000). Machinima, with its virtual characters and virtual settings presenting critical information and tasks in a simulated environment, may be an effective way of creating an authentic learning environment (Agostinho, 2006). It enables the creation of "engaging worlds in which students are actively involved in 'story-centric' problemsolving activities" (Mott, Callaway, Zettlemoyer, Lee \& Lester, 1999, p. 1). Machinima has the capacity to facilitate the development of the processes and knowledge students require for entry into a profession (Muldoon \& Kofoed, 2009).

At the Queensland University of Technology (QUT) School of Law, two programs - Air Gondwana and Entry into Valhalla - employ machinima created using the Second Life virtual world to create authentic learning environments for the teaching of negotiation skills and legal ethics, respectively.

\section{Air Gondwana}

Under the QUT School of Law's integrated program of graduate capabilities, particular skills are developed to different levels of attainment according to the stage in the degree (Christensen \& Kift, 2000). For example, the skill of negotiation is taught at a basic level in the first-year units (subjects) Contracts $A$ and Contracts $B$, then later developed to a higher level in the unit Trusts and further still in the elective unit Mediation. For several years, Contracts $A$ and Contracts $B$ adopted a traditional approach to teaching negotiation skills at a basic level, which included a lecture providing instruction in negotiation principles, print materials and role-plays. While on the whole this was well received by students, its effectiveness was questionable since it called for the performance of a number of underlying skills, many of which were not adequately developed by a passive learning approach. In addition, the Contracts $A$ and Contracts $B$ units posed their own challenges: enrolments in excess of 500 students annually and students studying via different modes of study, including full time, part time and distance/external. The deficiencies of the traditional approach and particular challenges posed by the units were addressed by Air Gondwana, a blended learning experience that incorporates multiple machinima videos.

Air Gondwana uses elements of a 'cognitive-apprenticeship' approach to learning including modelling, coaching, scaffolding, reflection and exploration (Brown, Collins \& Duguid, 1989; Collins, 1991). The program is based upon the contractual dealings of a fictional airline (Air Gondwana) and has a backdrop narrative involving, in essence, a wealthy industrialist who entrusts the running of one of his companies (the airline) to one of his sons as a test of his business acumen (Butler, 2008). This program comprises five modules accessed via the Blackboard learning management system (LMS). The first module consists of a real-life video that provides instruction on negotiation theory and practice and includes modelling of a negotiation (the hiring of a 
pilot) done poorly, and the same negotiation done well. The instruction on the principles of negotiation is illustrated through short vignettes demonstrating the proper steps to be taken in preparation for a negotiation. Modules 2 and 3 present a series of short scenarios (such as the commissioning of a new wardrobe for flight crew, maintenance contracts and charter contracts) in which students practise the application of the principles they have learnt across a variety of fact situations. These scenarios are illustrated by Second Life images.
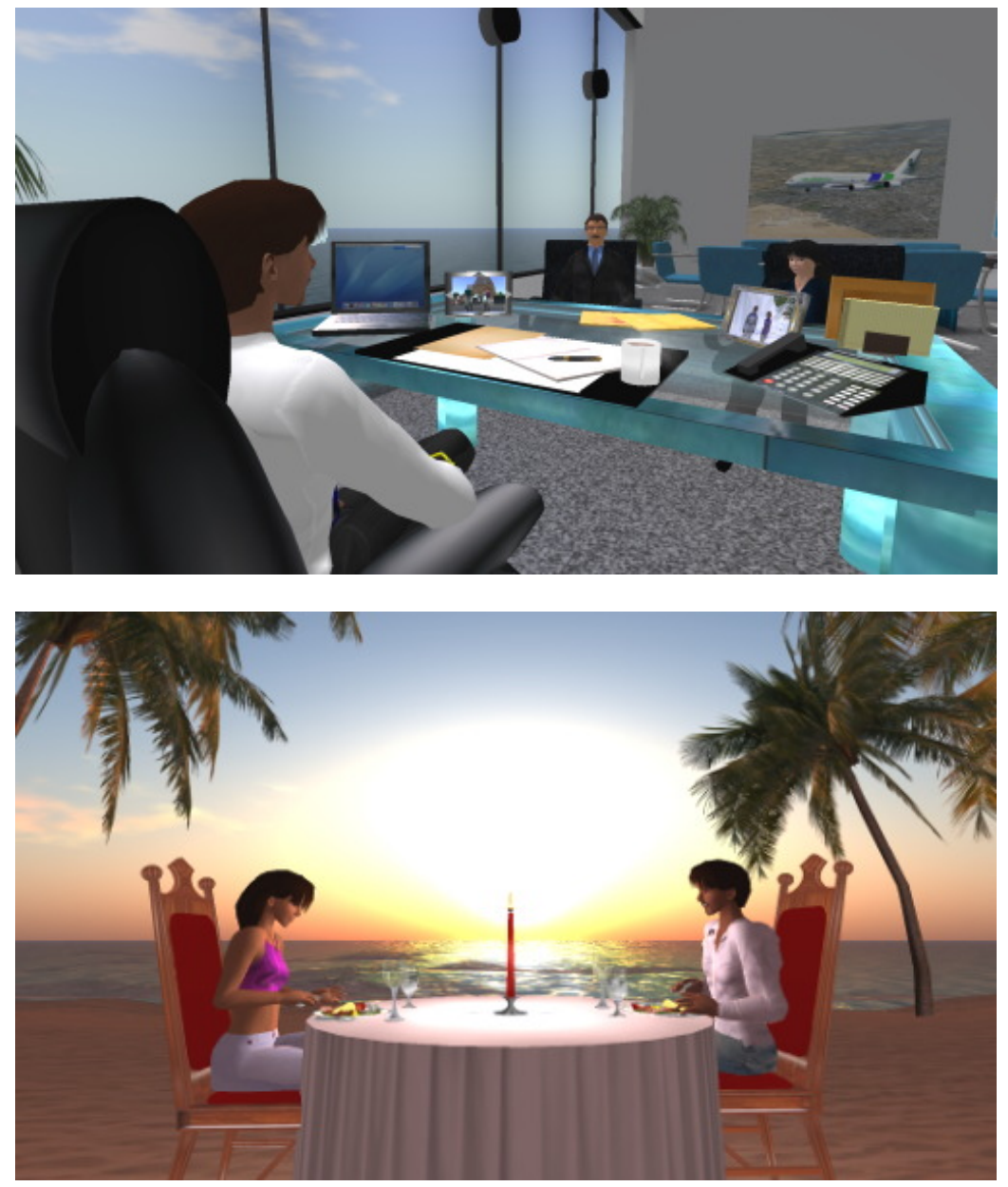

Figure 1: Scenes from Air Gondwana

Module 4 presents a single scenario (the purchase of an aircraft) in which students practise the application of the principles they have learnt to a more complex fact situation. This module incorporates Second Life machinima featuring the same characters that appeared in the Module 1 video, with the actors returning to provide the voices for their avatar representations (see Figure 1). The video pauses at various points, at which the student is asked questions concerning the application of negotiation theory as relevant to the unfolding story. Modules 2, 3 and 4 require students to enter their answers before being provided feedback against which they 
may compare their answers. Module 5 comprises a role-play in which the airline negotiates with an environmental group in relation to the purchase of a Pacific island. The role-play is undertaken in class (or at attendance school in the case of distance/external students). The necessary preparation materials, which are accessed online, include Second Life machinima that depicts the island, the various recreation activities and the airline's plans for its development. The debriefing of the role-play is done in part by Second Life machinima, which is shown in class.

\section{Entry into Valhalla}

In addition to legal ethics issues dealt with as part of different units it offers (for example, Contracts $A$ and Contracts $B$ deal briefly with ethics associated with contract dealings), the QUT Law School has a final-year unit wholly devoted to examining professional responsibility. In previous years, this material was covered by way of lectures and readings on the philosophical and theoretical underpinnings of legal ethics, followed by a workshop program consisting of short theory questions (e.g. "'The role of the Crown Prosecutor is not to secure a conviction at all costs.' Discuss.") and single-issue text-based problems (e.g. a set of facts might be described in which, for instance, one person is said to have committed a crime and at some later time confesses his or her guilt to a lawyer, with students asked to give their advice in the circumstances).

This approach was replaced by Entry into Valhalla, which, like Air Gondwana, utilises elements of a cognitive-apprenticeship approach. The program was created as part of an Australian Learning and Teaching Council (ALTC) Teaching Fellowship that focussed on using cost-effective multimedia, including machinima, to create engaging learning experiences for students (Butler, 2011). The program comprises five modules, accessed via the Blackboard LMS, that address different areas of the legal ethics curriculum (The Legal Profession, Admission to the Profession, Confidentiality and Conflicts of Interest, The Duty to the Administration of Justice and Discipline). Each of these includes an introductory video (in which an academic, filmed in the real world, gives an overview of the area to be studied), together with prescribed readings, self-test quizzes and Second Life machinima scenarios that depict real-world ethical dilemmas accompanied by questions based on those scenarios. The machinima scenarios, which are between four and seven minutes long, each follow the format of a legal practitioner in a fictional law firm approaching the male and female senior partners for advice concerning an ethical dilemma that the practitioner is confronting in the course of his/her work. Each scenario ends with the practitioner positing the question "What do you think?", or a variation thereof, to facilitate in-class discussions in which students role-play as either the male or female partner in providing advice to recognise and attempt to resolve the ethical dilemmas.

For example, in one machinima scenario dealing with a lawyer's overriding duty to the administration of justice, the narrative depicts the ethical dilemmas confronting a practitioner who is representing an 'obnoxious punk' charged with murder. The lawyer takes an instant dislike to the client and does not think him worthy of a defence. The client instructs the lawyer to use an alibi witness who the lawyer does not think is reliable, and ultimately admits, confidentially to the lawyer, that he is guilty of the crime. The machinima video comprises footage of the meeting between the legal practitioner and the two senior partners, flashback depictions of the crime and the practitioner's meetings with the client and alibi witness (see Figure 2). The video is 
only 4 minutes and 33 seconds long, but facilitates in-class discussion of 10 complex ethical issues, including whether a lawyer should ask a client if he/she committed the offence with which he/she is charged; whether a lawyer should withdraw from representing a client when the practitioner forms a low opinion of the client; whether a lawyer should follow a client's instructions to present an alibi witness when he/she does not think that witness is credible; what, if anything, a lawyer should do when the client confesses that he/she is guilty of the crime with which he/she is charged; and finally, what, if anything, a lawyer should do when the lawyer knows that a witness is committing perjury, as well as the prosecutor's responsibilities and obligations in such a case.
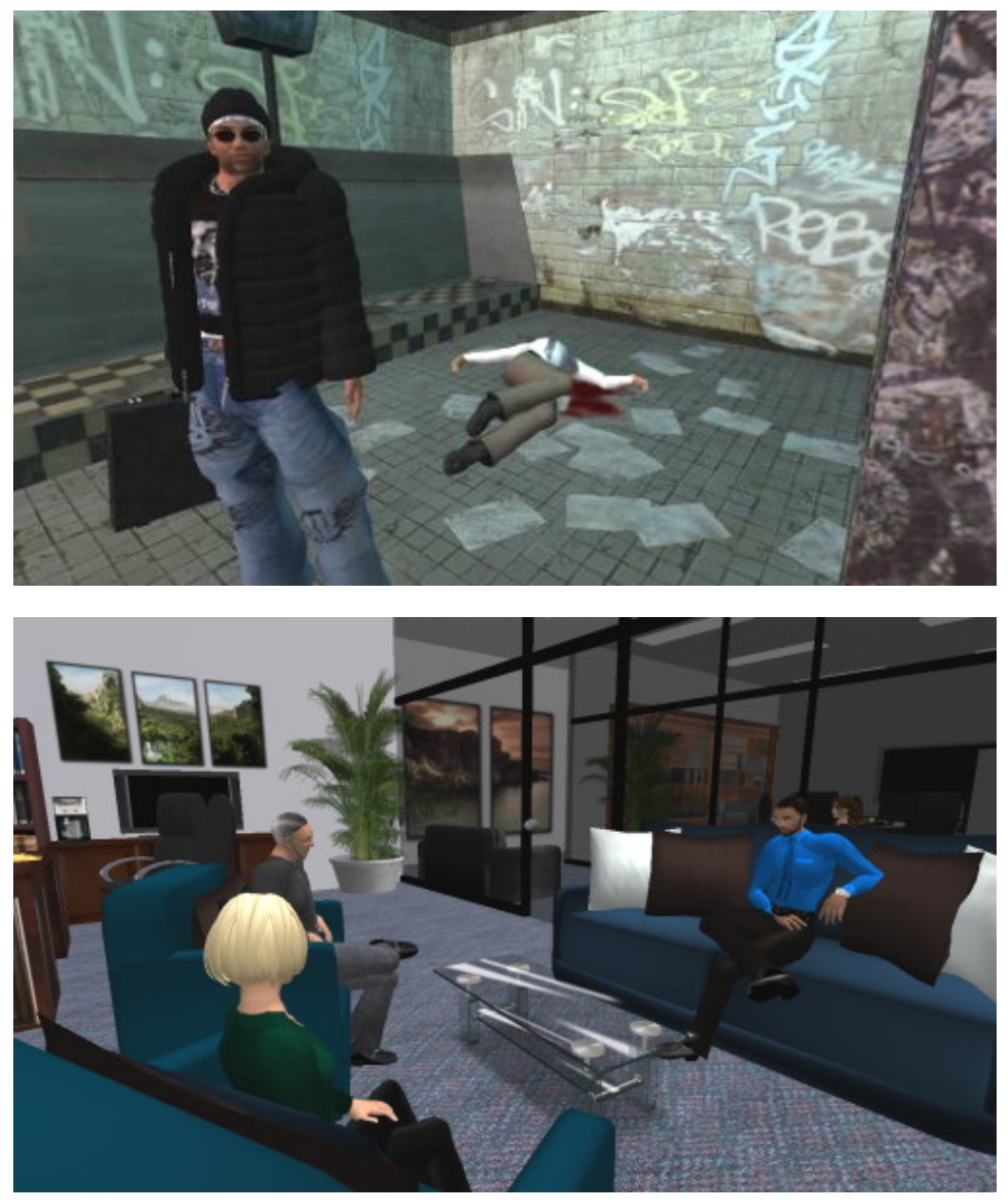

Figure 2: Scenes from Entry into Valhalla

\section{Student reactions and feedback}

Surveys were conducted for both Air Gondwana and Entry into Valhalla with a view to determining student opinion regarding the effectiveness of the programs as learning environments. Questions ranged across a number of aspects of the programs, and 
similar questions appeared on the two surveys. Some, but not all, of the questions were relevant to the use of machinima as a learning tool and its ability to create a learning environment that reflects a real-world context for the students' learning. In particular, questions sought to gauge their views regarding the extent to which the machinima provided an authentic setting to their studies by making connections with real-world practice, as well as the extent to which the machinima made study engaging and enjoyable for them. Students were also asked to draw comparisons between the use of machinima as a means of creating a learning experience, and learning by way of a traditional approach.

The surveys were conducted by way of paper instruments rendered in class. They comprised a combination of open-ended questions and statements to which students were asked to respond on a five-point Likert scale (where 5 represented 'strongly agree' and 1 represented 'strongly disagree'). The open-ended questions gave students the opportunity to explain, among other things, the features of the programs they found most helpful for their studies, along with any criticisms or problems they encountered in their use.

In the case of Air Gondwana, responses were received from 367 students, representing an $87.6 \%$ response rate (Butler, 2008); in the case of Entry into Valhalla, responses were received from 156 students, representing a 33\% response rate (Butler, 2011).

\section{Connections with real-world practice}

A total of $90.5 \%$ of respondents agreed or strongly agreed (and only $1 \%$ disagreed or strongly disagreed) that Air Gondwana helped them to understand the application of the principles of negotiation in practice. A total of $85.3 \%$ of them agreed or strongly agreed (as opposed to $2.1 \%$ who disagreed or strongly disagreed) that the fictional airline provided a realistic setting for them to understand the principles of negotiation. In terms of Entry into Valhalla, a total of $85 \%$ of students agreed or strongly agreed (while 4\% disagreed or strongly disagreed) that the program helped them to relate their understanding of legal ethics to real-world situations; a total of $84 \%$ of students agreed or strongly agreed (with 5\% disagreeing or strongly disagreeing) that the law firm storyline assisted their learning.

In both cases, the Second Life visuals, the storylines (the airline narrative in Air Gondwana and the law-firm scenarios in Entry into Valhalla) and the realism/real-world learning were nominated as the aspects of the programs most liked by students.

\section{Enjoyment in learning}

A total of $78.2 \%$ of respondents indicated that they agreed or strongly agreed that they enjoyed Air Gondwana, while a total of $77 \%$ of respondents agreed or strongly agreed that they enjoyed using Entry into Valhalla. This contrasted with the 3.2\% and 8\% respectively who indicated that they did not enjoy the programs.

\section{Comparison with traditional approaches}

When asked to compare these approaches to traditional approaches to instruction, a total of $92.7 \%$ of respondents agreed or strongly agreed $-57.8 \%$ strongly agreeing - that they thought they gained a better understanding of basic negotiation theory and 
practice from Air Gondwana than they would have from a single one-hour lecture and two unrelated role-plays (the previous approach taken to negotiation instruction). Only 2.2\% (8 students) would have preferred for the material to be covered by a traditional approach. Similarly, a total of $81 \%$ agreed or strongly agreed $-45 \%$ strongly agreeing - that the Second Life machinima scenarios in Entry into Valhalla were a more effective way to depict ethical dilemmas than the more traditional approach of textbased problems that is currently used in most Australian law schools. Only 6\% disagreed or strongly disagreed with this proposition.

\section{Second Life machinima and narrative learning}

For generations, storytelling has been used as a means of educating others about culture, customs and norms (Little Bear, 2000). As observed by Sarbin (1993), narratives provide "libraries of plots... [which] help us interpret our own and other people's experience" (p. 63). Narratives are constructed by drawing upon cultural elements such as normal events, reasonable causes and plausible explanations, all of which provide legitimacy for the narrative (Linde, 1993).

The use of narrative in higher education is not a new concept. In legal education, the 'law and literature' field of study draws connections between legal theory and literature, including William Shakespeare's The Merchant of Venice, Charles Dickens' Bleak House and Harper Lee's To Kill a Mockingbird (Posner, 2009). A limited form of narrative-centred learning is manifest in the form of the short problem-type questions commonly used by law schools in small-group tutorials to enable students to discuss the application of legal principles and rules in the context of fact scenarios. However, these scenarios are generally relatively light in detail and disconnected from one another.

A narrative learning environment can not only convey important information, but also provide contextual cues that facilitate recall of that information in situations in which it is likely to be applicable (Ferguson, Bareiss, Bimbaum \& Osgood, 1992). As Rowe, McQuiggan and Lester (2007, p. 126) comment,

Stories are unique in providing the ability to draw audiences into plots and settings, thereby opening perceptual, emotional, and motivational opportunities for learning... Narratives can facilitate students' semantically encoding new information and making commitments to long-term memory in the form of episodic memories.

A narrative may help learners to "create meaning, reduce cognitive load involved in navigating through information, and support cognitive and imaginative engagement" (Paulus, Horvitz \& Shi, 2006, p. 356).

Second Life machinima such as that in Air Gondwana and Entry into Valhalla adds a new dimension to a narrative-centred approach to learning. Machinima created using a virtual environment can be used "as a means of facilitating and accelerating the creative story development and storytelling process" (Berkeley, 2006, p. 75). A virtual environment like Second Life borrows assumptions from real life (Boellstorff, 2008). Second Life, with its ability to customise avatars, artefacts and environments, and to script the movement of avatars, facial expressions and objects, provides a rich canvas for customised storytelling and the simulation of realistic situations. The storylines in the two programs helped students in relating theory to more familiar understandings. As one student said of Entry into Valhalla: 
Putting the ethical issues into a real-world context was very helpful for me. I found the reading of [the theory] difficult to connect to practical examples on my own.

Another stated:

[The] storyline make it more interesting to follow. Stories made the questions easier to answer as could apply to real-life situations

\section{A student remarked in relation to Air Gondwana:}

I enjoyed the build up of a narrative and background story in the Air Gondwana videos and subsequent role-play. As a result of this, the role-play felt more realistic and involving.

The use of machinima and narrative-centred learning environments is also inclusive of a range of student learning styles and teaching strategies, providing students with the opportunity to visualise ideas and concepts (Burbules, 1999). One student observed in relation to Entry into Valhalla:

I think it provides a greater dimension to learning the theory in a practical way because the context/plots / characters give it a 'life' dimension... It suits my learning style. I find it really easy to retain the information and apply to the questions that are part of the program.

Machinima is able to initiate what the poet Samuel Taylor Coleridge first called a 'willing suspension of disbelief'. A willing suspension of disbelief allows us to enjoy movies like the Star Wars and Indiana Jones films and those involving the death-defying exploits of James Bond. It also allows us to relate to stories that are depicted using computer graphics, including modern computer games (Milburn, n. d.). It enables the viewer to relate to the characters depicted by computer graphics as if they were real people. This is demonstrated by comments made by students in relation to Entry into Valhalla. One stated:

It puts into real-world perspective, putting faces to names, seeing the people, makes it easier to relate to the situation.

The use of computer graphics need not be at the expense of the subtleties that can be conveyed by real-life actors. One student remarked, when contrasting the depiction of ethical dilemmas by machinima in Entry into Valhalla with the same kind of dilemmas described in text:

The video can depict more easily the non-verbal cues amongst parties and make it easier to understand how ethical dilemmas can arise and continue.

Another listed the advantages of depiction by machinima over text as:

(a) more interesting (b) easier to differentiate the characters (c) nuances of tone, body language more accurately portrayed, so easier to understand.

Machinima aids understanding by expanding the ability to depict a character beyond a name to not only a distinctive face, but also a distinctive voice:

It was easier when there were a lot of different characters to have a physical representation and different voices. Sometimes many parties/characters in written format become confusing. 
Herrington, Oliver and Reeves (2002) consider such willing suspension of disbelief associated with such authentic learning environments to be 'highly applicable' to education because it enables or facilitates engagement. According to Laurel (1993), "Engagement is what happens when we are able to give ourselves over to a representational action, comfortably and unambiguously. It involves a kind of complicity" (p. 115). Engagement may also be promoted by having fun when studying, which can itself be a powerful stimulus for learning (Bruner, 1960, p. 14). For example, as one student observed regarding Air Gondwana:

It was a much more interesting way to learn about negotiation than a lecture, and I think I learnt a lot more through this method that I otherwise would have. It wasn't boring and it engages you a lot more.

Another stated:

I felt as if I was 'learning' but it wasn't obvious that I was learning. I felt completely involved in the process.

Greater engagement can lead to enhanced knowledge construction (Herrington et al., 2002) and can in turn mean improved attention spans, accelerated absorption of key learning outcomes and longer-term retention (de Freitas, 2005).

Machinima enables the curriculum to be in a rich, multi-layered real-world context that more closely resembles situations students may encounter when they enter the workforce (Butler, 2011). As already noted, the machinima scenario in Entry into Valhalla concerning a lawyer's duty to the administration of justice lasts a mere 4 minutes and 33 seconds, and yet facilitates an examination of not only the role of a Crown Prosecutor and the appropriate response when a client confesses his or her guilt, but also eight other complex ethical issues arising in the same situation. This approach helps students realise that ethical dilemmas do not always yield to simple or peremptory answers, nor are they always as straightforward to resolve as the textbased problems they may be familiar with from their studies of other substantive law subjects:

Valhalla was good but so grey at times, hard to find answers - but this may just be a reflection of the area of study. It was definitely something different and was stimulating mentally.

The ability to depict rich detail is also capable of facilitating a degree of creative thinking not possible from the use of text-based materials alone. As a student said of Air Gondwana:

It was realistic and practical and enabled me to think outside the problem and apply basic common sense to reach an effective solution.

\section{Lessons for academics in producing effective machinima}

Apart from the prohibitive cost of production often associated with developing multimedia resources, including the cost of filming and of computer software programming, there are other obstacles to introducing multimedia innovations into curricula. These include a lack of technical literacy and/or commitment to learn new technology on the part of academics, a perceived threat to academic freedom and autonomy, and general 'academic inertia' (Middleton \& Mather, 2008). 
Multimedia innovation does not call for the substantial funding typically required for real-world film making. The machinima elements of both Air Gondwana and Entry into Valhalla were created using cost-effective resources. Second Life may be used for free. The video was recorded using the FRAPS screen-capture program, which is available for free in a version that places a small 'FRAPS' watermark at the top of the screen or in a 'clean' version for a fee of less than $A \$ 50$. Voices were supplied by suitably talented Faculty staff and supplemented by free sound effects available from Freeesound.org, with recording and mixing done using the free Audacity software. Video and sound clips were then edited together using Windows Movie Maker. The completed videos are accessed via Blackboard sites, either as standalone videos or as part of a package of video and text presented through Blackboard using the free Xerte program (Butler, 2008, 2011).

Naturally, these are not the only resources that may be used to produce machinima. Proprietary software can be purchased that offers more capability. For example, Sony's Vegas Home Studio might be used for video editing, and Adobe AIR or Articulate Quizmaker might be used for packaging the completed videos for access via an LMS but at the cost of purchasing the necessary software licences. Second Life might be accessed on a paid account, allowing for a permanent presence to be maintained between logins and allowing the filmmaking process to be simplified by removing the need to reconstruct sets before each use. However, the fact that free or low-cost alternatives are available means that academics without access to funding need not be denied the opportunity of introducing machinima into their courses due to the cost of multimedia production alone.

Even with easy access to the resources that enable the creation of machinima, academics require the technical proficiency and confidence to make use of those resources. The cost-effective resources used to produce Air Gondwana and Entry into Valhalla are intuitive to use; indeed, the author of the present article had no formal training in their use. There are also now numerous tutorials available online that provide instruction on how to use these tools. However, it must be acknowledged that gaining proficiency demands commitment on the part of the academic to learn the necessary skills.

Apart from the time taken to acquire the skills, production of programs like Air Gondwana and Entry into Valhalla can be a time-consuming exercise. Working alone, a five-minute machinima scenario can take an academic one to two weeks produce, with time required for the writing of scripts, storyboarding, building of any film sets, creation of the required avatar characters, filming of machinima sequences, recording of voice tracks and video editing. Collaboration may make the process quicker, but nonetheless a substantial time investment is required.

The above having been said, the time and effort demanded must be weighed up against the benefits that may be yielded by machinima scenarios in terms of the rich, engaging and flexible learning environment afforded to students, regardless of the size of the cohort, mode of study (on campus or distance/external) and whether they are enrolled full time or part time. The machinima scenarios are also a sustainable resource. If designed properly, the fact scenarios could be as relevant in 10 or 15 years as they are today, meaning that the machinima can form the basis of study for many year groups to come. 
Design of such programs should also accommodate equity issues. Both Air Gondwana and Entry into Valhalla provide videos in formats suitable for high-speed broadband as well as slower (e.g. dialup) connections. All videos are also supported by printerfriendly transcripts, which not only are suitable for students who are unable to properly view the videos, but also serve as a fallback in the event that the technology does not work for any reason.

It should also be anticipated that while machinima in programs like Air Gondwana and Entry into Valhalla may be engaging and effective learning resources for most modernday students, they may not receive universal approval. Research has identified that a small proportion of students (and academics) will resist the use of technology for teaching and learning, in particular where game-based and game-like designs are involved, as a result of a complex mix of personal and societal ideologies in relation to play and learning (deWinter et al., 2010; Gee, 2003). Entry into Valhalla is a good example. A small number of students criticised the program on the grounds that they had a preference for text-based learning, that it took longer to watch the videos (despite none being more than seven minutes long) than to read text, that text-based questions were what they were used to, and that the exam would be text-based and so all of the tutorial questions should also be text-based. These students generally were those who reported that they did not think the programs aided their learning. A single student expressed a more fundamental objection in that he/she viewed the use of computer graphics as being more appropriate to game play in primary school rather than university study. Regardless of the legitimacy or otherwise of these various criticisms, a simple measure to at least partially placate the concerns of these students is the provision of printer-friendly versions of transcripts as an alternative means for them to access the content of the narratives that form the basis of discussion in class.

\section{Conclusion}

Abstracted and decontextualised knowledge tends to dominate the pedagogical practices in traditional teaching methods, not only in law but also in many other disciplines as well (Muldoon, Jones, Kofoed \& Beer, 2008). In many cases, content is prioritised at the expense of depth, with limited opportunities for students to develop skills and attributes required in the professional work environment (Herrington \& Oliver, 2000, p. 23). The traditional 'transmissive' approach, epitomised by large-group lectures, also no longer meets the expectations or needs of today's students, who generally want flexibility in their studies to juggle the competing time commitments of study, work and family (Moreau \& Leathwood, 2006; Tarrant, 2006).

As Middleton and Mather (2008) noted, a blended curriculum drawing on digital media can be an effective means of promoting active, student-centred learning by setting challenges, seeding ideas and illustrating problems. A technology-based learning environment, with its asynchronous features, can heighten potential learning impact by letting the student user determine its timely application, thereby addressing the issue of flexible access to resources (Middleton \& Mather, 2008, p. 208). Machinima simulations created in an immersive, abstracted space offer students the opportunity to encounter authentic experiences involving other people, objects and environments. They enable students to take an active, practical approach to their learning rather than a passive, theoretical approach. They engage students and allow them to appreciate the relevance of what they are learning to the real world, thereby helping to facilitate their transition from study to their working lives. 


\section{Acknowledgments}

Entry into Valhalla was created as part of a 2009 Australian Learning and Teaching Council (ALTC) Teaching Fellowship titled 'Using cost-effective multimedia to create engaging learning experiences in law and other disciplines'. The ALTC was an initiative of the Australian Government Department of Education, Employment and Workplace Relations (DEEWR). It ceased operations in September 2011, and most of its functions have been transferred to the newly established Office of Learning and Teaching (OLT) within DEEWR. The views expressed in this article do not necessarily reflect the views of the ALTC, OLT and/or DEEWR.

\section{References}

Advisory Committee on Legal Education and Conduct (1996). First report on legal education and training. London: Her Majesty's Stationery Office.

Agostinho, S. (2006). Using characters in online simulated environments to guide authentic tasks. In A. Herrington \& J. Herrington (Eds), Authentic learning environments in higher education (pp. 88-95). Hershey, PA: Information Science Publishing. http: / / dx.doi.org/10.4018/9781591405948.ch007

American Bar Association (1992). Legal education and professional development - an educational continuum. Chicago: ABA.

Australian Law Reform Commission (1999). Managing justice: A review of the federal civil justice system (Report No. 89). Sydney: ALRC.

Berkeley, L. (2006). Situating machinima in the new mediascape. Australian Journal of Emerging Technologies and Society, 4(2), 65-80. http: / / www.swinburne.edu.au/hosting / ijets / journal/V4N2 / pdf/V4N2-1-Berkeley.pdf

Boellstorff, T. (2008). Coming of age in Second Life: An anthropologist explores the virtually human. Princeton, NJ: Princeton University Press.

Boon, A. (2002). Ethics in legal education and training: Four reports, three jurisdictions and a prospectus. Legal Ethics, 5(1-2), 34-67.

Brown, J. S., Collins, A. \& Duguid, P. (1989). Situated cognition and the culture of learning. Educational Researcher, 18(1), 32-42. http:/ / dx.doi.org/10.3102/0013189X018001032

Bruner, J. (1960). The process of education. Cambridge, MA: Harvard University Press.

Burbules, N. C. (1999). Technology in education: Who, where, when, what, \& why? International Journal of Educational Technology, 1(1).

http:// www.ascilite.org.au/ajet/ijet/v1n1/v1n1feature.html

Butler, D. (2008). Air Gondwana: Teaching basic negotiation skills using multi-platformed multimedia. Journal of the Australasian Law Teachers Association, 1(1-2), 213-226. http: / / www.alta.edu.au / pdf/JALTA/ (2008)\%20JALTA\%20Typeset\%20Articles / (2008)\%20 Air\%20Gondwana_D\%20Butler.pdf

Butler, D. (2011). Using cost-effective multimedia to create engaging learning experiences in law and other disciplines. Sydney: Australian Learning and Teaching Council. [viewed 1 Oct 2011] http:// www.olt.gov.au/system/files/resources/Butler_D_QUT_Fellowship_report_2011.pdf 
Castles, M. (2001). Challenges to the academy: Reflections on the teaching of legal ethics in Australia. Legal Education Review, 12(1-2), 81-104.

http: / / www.austlii.edu.au/au/journals/LegEdRev/2001/6.html

Christensen, S. \& Kift, S. (2000). Graduate attributes and legal skills: Integration or disintegration? Legal Education Review, 11(2), 207-237.

http: / / www.austlii.edu.au/au/journals/LegEdRev/2000/8.html

Collins, A. (1991). Cognitive apprenticeship and instructional technology. In L. Idol \& B. F. Jones (Eds), Educational values and cognitive instruction: Implications for reform. (pp. 453-494). Hillsdale, NJ: Erlbaum.

Dalgarno, B., Lee, M. J. W., Carlson, L., Gregory, S. \& Tynan, B. (2011). An Australian and New Zealand scoping study on the use of 3D immersive virtual worlds in higher education. Australasian Journal of Educational Technology, 27(1), 1-15. http:/ / www.ascilite.org.au/ajet/ajet27/dalgarno.html

de Freitas, S. I. (2005). Using games and simulations for supporting learning. Learning, Media and Technology, 31(4), 343-358. http:/ / dx.doi.org/10.1080/17439880601021967

deWinter, J., Griffin, D., McAllister, K. S., Moeller, R. M. \& Ruggill, J. E. (2010). Computer games across the curriculum: A critical review of an emerging techno-pedagogy. Currents in Electronic Literacy. http: / / currents.cwrl.utexas.edu/2010/dewinter_et_al_computer-gamesacross-the-curriculum

Dunning, J., Rogers, R., Magjuka, R., Waite, D., Kropp K., Gantz, T., ... Vandermolen, L. (2004). Technology is too important to leave to technologists. Journal of Asynchronous Learning Networks, 8(3), 11-21. http:/ / www.sloanconsortium.org/sites/default/ files/v8n3_dunning_1.pdf

Ferguson, W., Bareiss, R., Bimbaum, L. \& Osgood, R. (1992). ASK systems: An approach to the realization of story-based teachers. The Journal of the Learning Sciences, 2(1), 95-134. http: / / dx.doi.org/10.1207/s15327809jls0201_3

Gee, J. P. (2003). What video games have to teach us about learning and literacy. New York: Palgrave Macmillan.

Herrington, J. \& Oliver, R. (2000). An instructional design framework for authentic learning environments. Educational Technology Research \& Development, 48(3), 23-48. http: / / dx.doi.org/10.1007/BF02319856

Herrington, J., Oliver, R. \& Reeves, T. C. (2003). Patterns of engagement in authentic online learning environments. Australian Journal of Educational Technology, 19(1), 59-71. http: / / www.ascilite.org.au/ajet/ajet19/herrington.html

Johnstone, R. \& Vignaendra, S. (2003). Learning outcomes and curriculum development in law. Canberra: Australian Government Publishing Service.

Keyes, M. \& Johnstone, R. (2004). Changing legal education: Rhetoric, reality, and prospects for the future. Sydney Law Review, 26(4), 537-564.

http: / / www.sydney.edu.au/law/slr/docs_pdfs/editions/slr_v26_n4.pdf

Laurel, B. (1993). Computers as theatre. Reading, MA: Addison-Wesley.

Law Council of Australia (2008). Review of Australian higher education discussion paper. Canberra: LCA. [viewed 1 Oct 2011] http: / / www.deewr.gov.au/HigherEducation/Review / Documents / Submissions2008/209LegalEducationCommitteeLawCouncilofAustralia.pdf 
Le Brun, M. J. (2001). Enhancing student learning of legal ethics and professional responsibility in Australian law schools by improving our teaching. Legal Education Review, 12(1-2), 269-285. http: / / www.austlii.edu.au/au/journals/LegEdRev/2001/12.html

Linde, C. (1993). Life stories: The creation of coherence. Oxford, UK: Oxford University Press.

Little Bear, L. (2000). Jagged worldviews colliding. In M. Battiste (Ed.), Reclaiming indigenous voice and vision (pp. 77-85). Vancouver: University of British Columbia Press.

McGarr, O. (2009). A review of podcasting in higher education: Its influence on the traditional lecture. Australasian Journal of Educational Technology, 25(3), 309-321. http: / / www.ascilite.org.au/ajet/ajet25/mcgarr.html

Middleton, A. \& Mather, R. (2008). Machinima interventions: Innovative approaches to immersive virtual world curriculum integration. ALT-J, Research in Learning Technology, 16(3), 207-220. http: / / dx.doi.org/10.1080/09687760802526723

Milburn, D. (n. d.). The willed suspension of disbelief. [viewed 1 Oct 2011] http: / / www.texaschapbookpress.com/magellanslog8/disbelief.htm

Moreau, M. \& Leathwood, C. (2006). Balancing paid work and studies: Working (-class) students and higher education. Studies in Higher Education, 31(1), 23-42. http: / / dx.doi.org/10.1080/03075070500340135

Mott, B. W., Callaway, C. B., Zettlemoyer, L. S., Lee, S. Y. \& Lester, J. C. (1999). Towards narrative-centered learning environments. In M. Mateas \& P. Sengers (Eds), Narrative intelligence: Papers from the 1999 Fall Symposium (pp. 78-82). Menlo Park, CA: American Association for Artificial Intelligence. [viewed 1 Oct 2011]

http:/ / www.cs.cmu.edu/afs/cs/user/michaelm/www/nidocs/MottCallawayEtAl.pdf

Muldoon, N., Jones, D., Kofoed, J. \& Beer, C. (2008). Bringing 'second life' to a tough undergraduate course: Cognitive apprenticeship through machinimas. In Hello! Where are you in the landscape of educational technology. Proceedings ascilite Melbourne 2008.

http: / / www.ascilite.org.au/conferences/melbourne08/procs/muldoon.pdf

Muldoon, N. \& Kofoed, J. (2009). Second Life machinima: Creating new opportunities for curriculum and instruction. In G. Siemens \& C. Fulford (Eds), Proceedings of World Conference on Educational Multimedia, Hypermedia and Telecommunications 2009 (pp. 2243-2252). Chesapeake, VA: Association for the Advancement of Computers in Education. http://www.editlib.org/p/31789

Neale, M. A. \& Northcraft, G. B. (1990). Behavioral negotiation theory: A framework for conceptualizing dyadic bargaining. In L. L. Cummings \& B. M. Straw (Eds), Research in organizational behavior (Vol. 13, pp. 147-190). Stamford, CT: JAI.

New South Wales Law Reform Commission (1993). Scrutiny of the legal profession: Complaints against lawyers (Report No. 70). Sydney: NSWLRC.

Paulus, T. M., Horvitz, B. \& Shi, M. (2006). 'Isn't it just like our situation?' Engagement and learning in an online story-based environment. Educational Technology Research $\mathcal{E}$ Development, 54(4), 355-385. http: / / dx.doi.org/10.1007/ s11423-006-9604-2

Pearce, D., Campbell, E. \& Harding, D. (1987). Australian law schools: A discipline assessment for the Commonwealth Tertiary Education Commission. Canberra: Australian Government Publishing Service.

Posner, R. A. (2009). Law and literature (3rd ed.). Cambridge, MA: Harvard University Press. 
Robertson, M. (2004, 22-24 Sep). Renewing a focus on ethics in legal education. Paper presented at the Australian Lawyers and Social Change conference, Canberra. [viewed 1 Oct 2011] http:/ / anulaw.anu.edu.au/sites/all/files/users/u4081600/Conference_docs/mikerobertson.pdf

Roper, C. (1983). An approach to teaching lawyers negotiations. Journal of Professional Legal Education, 1, 51-57.

http:/ / www.heinonline.org/HOL/Page?handle=hein.journals / proleged1\&div=15\&g_sent=1

Ross, B. H. \& Kilbane, M. C. (1997). The effects of principle explanation and superficial similarity on analogical mapping in problem solving. Journal of Experimental Psychology: Learning, Memory, and Cognition, 23(2), 427-440. http:/ / dx.doi.org/10.1037/ / 0278-7393.23.2.427

Rowe, J. P., McQuiggan, S. W. \& Lester, J. C. (2007). Narrative presence in intelligent learning environments. In B. S. Magerko \& M. O. Riedl (Eds), Proceedings of the 2007 AAAI Fall Symposium on Intelligent Narrative Technologies (pp. 126-133). Menlo Park, CA: Association for the Advancement of Artificial Intelligence.

http: / / www.aaai.org/Papers/Symposia/Fall/2007/FS-07-05/FS07-05-021.pdf

Sarbin, T. R. (1993). The narrative as the root metaphor for contextualism. In S. C. Hayes, L. J. Hayes, H. W. Reese \& T. R. Sarbin (Eds), Varieties of scientific contextualism (pp. 51-65). Reno, NV: Context.

Stuckey, R. (2007). Teaching with purpose: Defining and achieving desired outcomes in clinical law courses. Clinical Law Review, 13(2), 807-838.

http: / / www.heinonline.org/HOL/Page?handle=hein.journals / clinic13\&div=27\&g_sent=1

Sugarman, D. (1986). Legal theory, the common law mind and the making of the textbook tradition. In W. L. Twining (Ed.), Legal theory and common law (pp. 26-62). Oxford, UK: Blackwell.

Tarrant, J. (2006). Teaching time-savvy law students. James Cook University Law Review, 13, 64-80. http: / / www.austlii.edu.au/au/journals/JCULRev/2006/4.html

Tyler, M. C. \& Cukier, N. (2005). Nine lessons for teaching negotiations skills. Legal Education Review, 15(1-2), 61-86. http:/ / www.austlii.edu.au/au/journals/LegEdRev/2005/4.html

Web, J. S. (1996). Why theory matters: Challenging the dominant epistemology of legal education. In J. S. Web \& C. Maughan (Eds), Teaching lawyers' skills (pp. 23-51). London: Butterworths.

Author: Professor Des Butler
Faculty of Law, Queensland University of Technology
2 George Street, Brisbane QLD 4000, Australia
Email: d.butler@qut.edu.au
Des has been using technology-based innovations to enhance the learning of law since
1990, and was awarded a Carrick Institute for Learning and Teaching in Higher
Education Award for Teaching Excellence for his work, including Air Gondwana. In
2009, he was awarded an Australian Learning and Teaching Council (ALTC) Teaching
Fellowship for a program that included the creation of Entry into Valhalla.
Please cite as: Butler, D. (2012). Second Life machinima enhancing the learning of law:
Lessons from successful endeavours. In M. J. W. Lee, B. Dalgarno \& H. Farley (Eds),
Virtual worlds in tertiary education: An Australasian perspective. Australasian Journal
of Educational Technology, 28(Special issue, 3), 383-399.
http:/ / www.ascilite.org.au/ajet/ajet28/butler.html

